\title{
К ВОПРОСУ О СПОСОБАХ МИНИМИЗАЦИИ ТОКСИЧЕСКОГО ЭФФЕКТА У ЛЕКАРСТВЕННЫХ ПРЕПАРАТОВ
}

\begin{abstract}
В.П. Иванова
ФГБУН Институт эволюционной физиологии и биохимии им. И.М.Сеченова Российской академии наук, 194223, Россия, Санкт-Петербург, пр. Тореза, 44.
\end{abstract}

DOI: 10.19163/MedChemRussia2021-2021-453

E-mail:valet@iephb.ru

Синтетические и природные лекарственные соединения при введении в организм человека часто вызывают токсический эффект, который варьирует в зависимости от использованной дозы и способа введения в организм. При этом нежелательные последствия могут быть системными или могут поражаться органы, не являющиеся мишенями данного лекарственного препарата. Одним из способов минимизации подобных побочных явлений является фоновое введение пептидных соединений, которые не вызывают интоксикацию у человека или животного.

Известный природный антибиотик блеомицин при терапии злокачественных новообразований вызывает развитие диффузного альвеолита с переходом к фиброзированию легочной ткани, которое сопровождается быстрой потерей дыхательной активности легких. Поиск лекарственных препаратов, замедляющих процесс фиброзной трансформации легочной ткани, остается актуальным и в настоящее время.

Изучено действие тимопентина, фрагмента 32-36 тимопоэтина (ТП-5), на первую фазу развития фиброзирующегоальвеолита, вызванного введением блеомицина, у крыс Вистар. Животным однократно интратрахеально вводили в легкие блеомицин (10 мг/кг), затем в течение 5 дней вводили ТП-5 (100мкг/кг). На 7-ой день после введения блеомицина проводили забор бронхоальвеолярного лаважа (БАЛ). В липидном экстракте БАЛ определяли содержание продуктов ПОЛ - диеновых коньюгатов (ДК) и шиффовых оснований (ШО).Показано, что ТП-5 ингибировал накопление первичных (ДК) и конечных (ШО) продуктов ПОЛ в мембранах фагоцитирующих клеток, входящих в состав БАЛ, на фоне инстилляции блеомицина крысам. ТП-5 снижает окислительную деструкцию жирнокислотных остатков в фосфолипидах мембран фагоцитов на стадии острого воспаления в ходе альвеолярного повреждения легких, вызванного введением блеомицина.

Главное ограничение для широкого использования ТП-5 в клинике связано с малым периодом циркуляции пептида в организме. Последнее можно нивелировать, используя синтетические инертные средства доставки, ограничивающие распад пептида, или синтезируя циклические аналоги ТП-5 с исходными параметрами, определяющими устойчивость препарата к протеолизу. 